NBER WORKING PAPER SERIES

RESEARCH AND IMPACTS OF DIGITAL FINANCIAL SERVICES

\author{
Dean Karlan \\ Jake Kendall \\ Rebecca Mann \\ Rohini Pande \\ Tavneet Suri \\ Jonathan Zinman \\ Working Paper 22633 \\ http://www.nber.org/papers/w22633
}

\author{
NATIONAL BUREAU OF ECONOMIC RESEARCH \\ 1050 Massachusetts Avenue \\ Cambridge, MA 02138 \\ September 2016
}

Jake Kendall and Rebecca Mann worked for the Bill and Melinda Gates Foundation while writing this paper and the Foundation sponsored some of the research presented in this paper. The views expressed herein are those of the authors and do not necessarily reflect the views of the National Bureau of Economic Research nor of the Bill and Melinda Gates Foundation.

NBER working papers are circulated for discussion and comment purposes. They have not been peer-reviewed or been subject to the review by the NBER Board of Directors that accompanies official NBER publications.

(C) 2016 by Dean Karlan, Jake Kendall, Rebecca Mann, Rohini Pande, Tavneet Suri, and Jonathan Zinman. All rights reserved. Short sections of text, not to exceed two paragraphs, may be quoted without explicit permission provided that full credit, including $\odot$ notice, is given to the source. 
Research and Impacts of Digital Financial Services

Dean Karlan, Jake Kendall, Rebecca Mann, Rohini Pande, Tavneet Suri, and Jonathan Zinman

NBER Working Paper No. 22633

September 2016, Revised September 2016

JEL No. G21,O12

\section{ABSTRACT}

A growing body of rigorous research shows that financial services innovations can have important positive impacts on wellbeing, but also that many do not. We first describe the latest evidence on what works in financial inclusion. Second, we summarize research on key financial market failures and on products and innovations that address specific mechanisms underlying them. We conclude by highlighting open areas for future work.

Dean Karlan

Department of Economics

Yale University

P.O. Box 208269

New Haven, CT 06520-8629

and CEPR

and also NBER

dean.karlan@yale.edu

Jake Kendall

Caribou Digital

kendall_jake@hotmail.com

Rebecca Mann

Bill and Melinda Gates Foundation

Seattle, WA

rebecca.mann@gatesfoundation.org
Rohini Pande

Kennedy School of Government

Harvard University

79 JFK Street

Cambridge, MA 02138

and NBER

rohini_pande@harvard.edu

Tavneet Suri

MIT Sloan School of Management

100 Main Street, E62-517

Cambridge, MA 02142

and NBER

tavneet@mit.edu

Jonathan Zinman

Department of Economics

Dartmouth College

314 Rockefeller Hall

Hanover, NH 03755

and NBER

jzinman@dartmouth.edu 


\title{
Research and Impacts of Digital Financial Services
}

\author{
By: Dean Karlan, Jake Kendall, Rebecca Mann, Rohini Pande, Tavneet Suri Jonathan Zinman
}

\section{The value of financial services in the lives of the poor - what works and why?}

The roughly 2.5 billion people in the world who live on less than $\$ 2$ a day are not destined to remain in a state of chronic poverty. Every few years, somewhere between 10 and 30 percent of the world's poorest households manage to escape poverty. Typically this is done by finding steady employment or through entrepreneurial activities such as growing a business or improving agricultural harvests. During that same period, however, roughly an equal number of households slip below the poverty line. Health-related emergencies are the most common cause, but there are many more: crop failures, livestock deaths, farming-equipment breakdowns, and even wedding expenses.

In many situations, financial tools such as personal savings, insurance, credit, or cash transfers from family and friends are important buffers against crippling setbacks. However, key market failures, such as imperfect information, behavioral biases, high transaction costs, property rights which are not enforceable, and lack of competition, create wedges that inhibit the delivery of traditional financial services. The volatile income and subsistence status of the poor also exacerbate the nature and welfare implications of these market failures. Digital financial platforms offer many promising opportunities to dramatically improve both products and the market environment, but require care and a nuanced understanding of the market failures that currently plague poor families.

A growing body of rigorous research shows that financial services innovations can have important positive impacts on wellbeing, but also that many do not. We first describe the latest evidence on what works in financial inclusion. Second, we summarize research on key financial market failures and on products and innovations that address specific mechanisms underlying them. We conclude by highlighting open areas for future work.

\section{Rigorous evidence on welfare impacts of financial interventions for poor households}

Below, we review the basic evidence of impacts for credit, savings, insurance and payments. All but a few of the findings we cite were generated through randomized control trial studies (see Appendix A for list of studies).

1. Impact evidence on traditional one size fits all microcredit is mixed but, in general, fails to deliver on the historic claims:

Seven randomized evaluations from around the world show that the traditional one size fits all microcredit product - which is associated with high repayment and low default - did not increase average income or consumption of households. Expanded access to this product did lead some entrepreneurs to increase business investments, but rarely increased profits, (though for a subset of existing entrepreneurs, did produce significant improvements in one study). None of the studies found an impact on borrowers' average household income and only one found an impact on decision-making power for women within the household, (Banerjee et al., 2015 , IPA/J-PAL Policy Bulletin, 2015). That said, other forms of credit have shown more promise including short term credit to smooth consumption in the lean season which lead to a 10 percent increase in farm output, (Fink et al., 2014); and short term consumer credit in South Africa which lead to 11 percent more maintaining a job, (most likely by helping to absorb shocks that took people out of the labor force), higher income and stronger credit scores, (Karlan and Zinman 2010). 


\section{Impact evidence on savings indicate replicable positive household welfare impacts:}

Without being exhaustive, we highlight research into the impact of savings products, (see Karlan et. al., 2014 for a more complete review). With basic savings products, eliminating account opening costs in Kenya significantly increased uptake, overall savings, and investment levels among market vendors, (Dupas and Robinson, 2013a). Replication studies in Uganda, Malawi and Chile, (Dupas et al. 2016), also found that removing account opening costs increased savings, but was partially offset by a reduction in informal savings. Ultimately, there were no impacts on business investment or income in the three replications. In Nepal, offering femaleheaded households a no-fee basic account with deposit collection service led to high uptake and usage, with 80 percent still using the account after one year. Households responded better to health shocks and spent 20 percent more on education and 15 percent more on meat and fish, (Prina, 2015). In rural Malawi, farmers with access to savings accounts preserved more savings throughout harvest and planting seasons. They increased cultivated land by 7 percent, crop output by 15 percent, and expenditure by 10 percent (Brune et al., 2016). For village savings groups in Mali, researchers found improvements in buffer stock savings, food security and consumption smoothing, (Beaman et al., 2014). In Uganda, Malawi and Ghana, impacts were on food security, consumption during droughts, business investment and women's empowerment, (Karlan et al., ongoing).

Commitment savings products have lock up periods, fees, or other penalties for early withdrawal that "commit" the client to the savings goal. Women offered an individually-held commitment savings account in the Philippines reported increased decision-making power within the household, (a 0.14-0.25 standard deviation increase in an index of decision-making), with even larger effects for women who started out with below-median decision-making power. Durable goods purchased also shifted towards "female-oriented" goods, e.g. washing machines and kitchen appliances, (Ashraf et al., 2010). In Kenya, a simple "Safe Box" that allowed users to save for preventive or emergency health in a metal box to which they had a key increased achievement of health savings goals by 14 percentage points, (Dupas and Robinson, 2013b). In Uganda, primary school students who were offered a soft commitment savings account, (funds were available for withdrawal but simply labeled as being "for education"), combined with a parental outreach program on how to support child education increased spending on school supplies and improved test scores by 0.14 standard deviations, (Karlan and Linden, 2016).

Overall, savings accounts for low income households demonstrate strong potential to improve client welfare. Often the beneficial impacts of savings accounts require account features that help people overcome behavioral biases such as fortifying willpower and memory, (see below for more on biases). They may also require easier "on-ramps", given that uptake and active usage remain puzzlingly low despite positive impacts. These features will become easier to deliver with the advent of digital platforms which can be configured to create sub accounts, labeling, real time information, and other decision aids.

\section{Impact evidence on insurance is small but potentially promising however current business models fail to deliver scale}

Research on insurance has been largely focused on agriculture, though a number of ongoing studies examine health insurance. In Ghana, farmers who received a rainfall index insurance grant cultivated more land and spent 13 percent more on fertilizer and labor than those who received cash grants, implying that uninsured risk - not lack of access to capital - is a primary constraint for farmer growth, (Karlan et al., 2016). In India, when farmers were given rainfall index insurance, 6 percent more farmers focused production towards higher-return but higherrisk cash crops, (Cole et al., 2013, 2014). However, despite the potential of insurance products 
to provide a "risk floor" for farmers and encourage higher productivity investments and behavior, uptake at market prices is extremely low so microinsurance is not at scale anywhere except when heavily subsidized by government.

\section{Early impact evidence on payments and digital financial services indicates significant benefit}

Digital payments can significantly enhance client well-being both directly as well as through enabling a broader ecosystem. In Kenya, M-PESA helped households strengthen their informal risk-sharing networks, enabling them to better respond to shocks by borrowing or receiving gifts from friends and relatives: non-users of M-PESA reduced consumption by 7 percent in response to income shocks, while users' consumption was unresponsive to the shocks. The mechanism underlying this improvement was domestic remittances: users were more likely to receive remittances in response to a shock, they also received more, from more different types of people. These improvements in risk-sharing led to higher savings, higher consumption and changes in occupation for user households, (Jack and Suri, 2014, 2015; Suri et al., 2012).

In India, biometrically authenticated cards for workers employed by a 19-million person public works program reduced corruption, (Muralidharan et al., forthcoming). It increased labor market competition, with private-sector wages rising more than public-sector wages, suggesting an overall economic benefit for the population, (Muralidharan et al., forthcoming; Imbert and Papp, 2015; Zimmerman, 2015). Digital systems are also being used to disburse cash transfers with effects on the cost effectiveness of the distribution as well as on nutrition, (Aker et al., 2014) and to provide salaries (Callen et al., 2015). The use of digital systems for government to person transfers has had implications for public expenditure management systems - Banerjee et al., 2016 show that using digital financial services in India to transfer program funds for the same public works program enabled a 38 percent reduction in program fund expenditure and a 25 percent decline in corruption. Household transfers were unaffected, pointing to significant efficiency gains for them and the public exchequer.

\section{Understanding underlying market failures is the key to designing products and interventions that will generate welfare benefits for clients}

Client welfare benefits are created when innovations overcome fundamental market failures. RCT research is most powerful when it goes beyond simple evaluation and is used to understand the more fundamental market failures against which new generations of products can be designed. This section takes a step back from the question of welfare and focuses on the mechanisms - the underlying market failures and distortions - and interventions to overcome them.

Economic theory highlights the need for the free flow of information, rational behavior, low transaction costs, enforceable property rights, and competition in order to achieve efficient markets. In developing economies, market failures and distortions are so strong that all five conditions often fail at once. Understanding the mechanisms is critical to designing better strategies:

\section{Information asymmetries are a common source of market failure}

(a) Supply side - Adverse selection and moral hazard are two classic causes of market failure. Adverse selection occurs when providers, (lenders or insurers) cannot easily distinguish highrisk from low-risk, implying the need to work to screen clients, such as by using "big data" predictive models for default. Moral hazard occurs when providers are unable to enforce how much effort and care clients take to repay or avoid insurance losses. If moral hazard is pervasive, alternative mechanisms to increase the benefits of "good" choices are needed, (e.g., 
credit bureaus that reward repayment through improved access to future credit, reminders to repay loans, and property rights that facilitate enforcement).

Several business practices or policies can serve to minimize adverse selection and moral hazard while increasing access. For example, introducing a credit bureau across the branches of a Guatemalan microfinance lender improved screening ability, (27 percent more loans with no portfolio deterioration), while also increasing repayment rates and reducing delinquencies among existing borrowers, (De Janvry et al., 2010). In Malawi fingerprinting for microloans caused high-risk borrowers to take out smaller loans and to improve repayments - 85 percent of high-risk borrowers fully repaid their loans, relative to 44 percent in the comparison group, (Gine et al, 2012).

In Kenya, working with a savings and credit cooperative, Jack et al., 2015 compared offers for an asset collateralized loan, (the asset is repossessed on default), to a standard guarantor based loan for the same asset. Uptake rates were considerably higher, (44 percent), for the asset collateralized loan, relative to the guarantor contract, (2 percent), but repayment rates were similar, implying that guarantor contracts heavily over screen clients. Karlan and Zinman, 2009 separate out adverse selection and moral hazard for consumer loans in South Africa, and find that the incentives of lower future loan prices have large impacts on current repayment.

Evidence also shows that information asymmetries may inhibit the market provision of microcredit products that move away from the one-size fits all model. Field et al., 2013 found an immediate and positive effect of introducing a two-month grace period before microcredit loan repayment starts: the rate of business formation doubled and loan investment into the business increased. Three years on, household income was 19.5 percent higher and business profits nearly doubled, however, grace period clients were more than three times more likely to default, (albeit from a very low base). Modifying the repayment schedule was similarly important: switching repayment frequency from weekly to monthly more than doubled business income, increased household income by about 8 percent, reduced financial stress and in this case left default rates unchanged, (Field et al., 2012). Use of risk-based pricing, credit bureaus and administrative data for client screening - by lowering adverse selection -- could greatly enable product diversity that enhances client wellbeing.

As credit moves to become more digital, (e.g. M-Shwari in Kenya) adverse selection may become less key for the provider as borrower selection all happens digitally, (via a machine learning or other scoring algorithm). Experimentation with credit scoring algorithms may be a low cost way to dramatically reduce the importance of adverse selection, (Suri et al., ongoing work in Kenya).

(b) On the demand or consumer side - Information asymmetries also matter for consumers. For instance, a failure to understand the products being offered, (e.g. due to failure to comprehend or because providers fail to disclose information), may cause consumers to make poor decisions or withdraw from the market.

A large bank in Turkey informed consumers of a 50 percent rebate on overdraft protection interest charges, which actually reduced usage by 2 percent relative to clients who did not receive the rebate - the rebate backfired because it reminded consumers how much they were paying, (Alan et al., 2015). In Mexico, an anonymous "mystery shopping" audit of microcredit loan officers found that low-income borrowers received little disclosure information, (only 30 percent received any printed information), and were rarely offered the most affordable or suitable product (Gine et al., 2014).

Financial literacy has been the go-to intervention by many to tackle such information market failures, despite a weak evidence base. A meta-analysis, (Miller et al., 2014), from evaluations 
of 188 financial education programs found that, on average, these programs have not had positive impacts on financial knowledge or behavior and even where it worked, improvement was minimal and uptake was low. However, programs that incorporate simplified behavioral insights can be successful, such as teaching simplified rules-of-thumb, (Drexler et al., 2014). Researchers are now testing the impact of delivering rule-of-thumb information via SMS in India, (Cole and Schoar, ongoing).

\section{Rational behavior is not always a safe assumption}

There is now a large literature documenting financial behavior that is inconsistent with standard economic notions of rationality -- real humans exhibit systematic biases and limitations. An increasingly diverse body of work documents successful strategies for increasing savings, which has improved client welfare in many cases. Often these strategies amount to simple design choices and so are effectively cost free on the margin. For example, in Bolivia, Peru, and the Philippines, where people who received SMS reminders, (which have a near-zero marginal cost), to save had 6 percent higher savings relative to those who received no reminders, (Karlan et al., 2014). Amongst low-income farmers in China, researchers found that pension contributions in a government-backed pension scheme could be increased by 19 percent simply by showing an example of expected pension benefits. Contributions increased by 40 percent among those who were shown the example and taught the concept of compound interest, (Song, 2015). A wide variety of other features have been shown to augment savings behaviors, including: (i) commitment savings products, (ii) text message reminders for savings and similar reminders to repay loans, (see Cadena and Schoar, 2011 for Uganda and Karlan et al., forthcoming for the Philippines), (iii) automatic savings contributions or default retirement account enrollment, (Beshears et al., 2008, Benartzi and Thaler, 2004); examples from lowincome countries include defined-contribution savings on mobile money in Afghanistan, (Callen et al., 2015), automatic withdrawal of savings from salary payments in Ghana, (Buehren et al., ongoing), automatic withdrawal of insurance premiums from harvest proceeds for sugarcane farmers in Kenya, (Casaburi and Willis, 2015).

\section{Transaction costs can generate market distortions}

High transaction costs can affect both provider willingness to serve the poor and client willingness to use financial services. Historically, bank branches are few and far between and formal bank accounts often came with additional transaction costs such as obtaining formal identification documents, long wait times, poor service, high withdrawal fees and high required minimum balances. Intermedia surveys in 8 countries show the poor often cite time, cost and difficulty of establishing their identity in order to open an account as major barriers to access. ${ }^{1}$

Reducing transaction costs, (e.g. with digital platforms), can create large efficiency gains in financial markets. Research in Kenya showed that digital payment services dramatically reduced transaction costs in informal markets, strengthening and growing risk-sharing networks, and thus facilitating households' ability to respond to shocks, (Jack and Suri, 2014). Replications of this study are ongoing for Tanzania, Uganda and Pakistan. In related work, researchers are studying how digital financial products should be optimally designed given they are accessed and disbursed entirely digitally without any face to face interaction. This has implications for the provider on how to analyze client risk, how to collect payments, how to optimally cross-sell products without in-person interactions, (Almazan et al, 2013), how to deal with higher default and how to manage their portfolio. In addition, client behavior may be dramatically altered for better or worse through instant access to products and information, new user interfaces and many other changes, (Benartzi and Lehrer, 2015).

\footnotetext{
${ }^{1}$ India, Bangladesh, Pakistan, Indonesia, Kenya, Tanzania, Uganda, and Nigeria
} 
Despite the rise of digital financial services, many of the world's poor still function in a cash economy pointing to the importance of understanding the interface with the digital financial system. For instance, despite the introduction of digital transfers, research in rural India shows that last mile banking agents have power to influence who gets paid and how much, (Field at al., ongoing). In such a setting group trainings of the less literate and empowered groups on how to navigate digital financial services increased account usage and deposits, (Field et al., ongoing).

\section{Incomplete property rights often disadvantage women}

Power imbalances and limited control over ones property and assets can drive inefficiencies across social groups and within the household. For instance, women often lack rights to control resources in a manner equitable with men and, therefore, independent access to financial services. Research shows the importance of products that enable women to access financial services in such scenarios. For instance, good product design can help women circumvent social norms that restrict their mobility: women in Indian microfinance groups that met weekly were up to 32 percent more likely to pool resources and three times less likely to default on loans than groups that met monthly, implying that group lending may be beneficial not only due to social accountability, but also due to social interaction itself, (Feigenberg et al., 2013). A study on business training found that, relative to women trained alone, those trained with a friend were twice as likely to take out a loan and had 11 percent higher household income four months later, effects that were larger for women belonging to groups with more restrictive social norms. (Field et al., forthcoming). Schaner, 2015 found that the issuance of ATM cards reduced account usage by 0.19 standard deviations for women in Kenya with low levels of bargaining power, but increased it for women with high levels of bargaining power. The researchers believe the women with low bargaining power were apt to have their cards taken by their husbands and relatives to withdraw funds. In the randomized trials on traditional one-size fits all microcredit, only one study found impacts on female decision-making power while savings interventions show more success, (Ashraf et al., 2010). These findings suggest that creating diverse financial products that address the specific constraints faced by less empowered groups can yield high returns.

\section{Imperfect competition can be a double edged sword}

The intersection of the mobile and financial industries poses unique policy challenges in the area of competition. Sitbon (2016) documents a number of areas where "competition bottlenecks" have emerged in developing markets but cautions that policy interventions targeting monopolistic behavior need to be carefully timed and must balance the benefits of monopoly power as incentive to invest and drive growth, against the drawbacks of higher prices and slower innovation. Another line of relevant research relates to the monopoly of bank providers in various settings. In South Asia, for instance banks have historically had a monopoly for subsidized credit in geographically defined regions. Cole, 2009 finds that banks that have monopoly over disbursement of government-funded agricultural credit increase disbursement by 5-10 percentage points in an election year, and that this credit fails to increase agricultural output implying inefficient credit allocation. However, studies on market power and its implications for financial services are few and far between - there is more to be done.

\section{Returning to the goal of increasing income for the poorest: An integrated approach}

The poor are often afflicted by multiple overlapping market failures that mute the benefits of a single intervention. While many hoped that the traditional one size fit all microcredit would increase income for the world's poorest, it has neither reached the poorest of the poor, nor 
increased average income of those it has reached. Alternatively, a recent effort, (originally developed by BRAC in Bangladesh), has tested an integrated approach -- one that requires subsidy to operate -- but aims to more directly and effectively improve income for the world's poorest. The "Graduation" programs provide an integrated set of products and services to households, some financial, along with a substantive productive asset, training, and consumption support. These programs have been tested in seven countries now and have found large impacts as far out as seven years. Pooled data from six countries, (Banerjee et al., 2015), show Graduation households' consumption increased 7.3\%-Bangladesh, 16.4\%Ethiopia, 6.9\%-Ghana, 13.6\%-India and 10.2\%-Pakistan, 3\% Peru. Most positive impacts on participating households were consistent three years after intervention and preliminary results from a seven year follow up in India find even stronger results after seven years. Households experienced similar improvements in food security, asset holdings, and savings, as well as some indicators of psychosocial well-being and female empowerment. This is an example of how a program combines provision of financial instruments with other policies to ultimately address multiple market failures, (on both supply and demand sides), at once.

\section{Conclusion and strategic implications going forward}

A major challenge going forward is how to extend and operationalize the body of knowledge represented here in a new generation of products, policies, and strategies which are more fact based. Major hurdles in the way of this goal include: How do we further the development of products that are both attractive to and beneficial for users? How do we align other funders and governments around the right approaches to maximizing welfare? And how do we align business model incentives around products and services that benefit the poor most effectively?

Along these lines, the evidence base suggests some important emerging lessons that raise key questions for the field:

1. How to support the delivery of advanced savings products? A number of studies now all support the conclusion that client welfare can be significantly improved through savings products with commitment features and other decision aids to guide clients toward better financial planning and hard to reach savings goals. Despite the gain to clients, few successful commercial DFS products exhibit these features. How do we support the market to create products that more effectively help people save?

2. Is there a viable model for insurance? The poor live risky lives. The limited research on formal insurance does show benefits to farmers and even accelerating the informal insurance patterns through better P2P transfers has produced benefits. Unfortunately, the business model around for-profit insurance delivery to the poor is completely fraught with no known success cases, while government delivery of insurance is often ineffective and inefficient. New automated weather index models using satellite data and mobile payments show promise but current iterations are not yet viable. Are there viable models to insure poor households and in particular, smallholder farmers?

3. How to scale safe digital credit? Despite the disappointing results from evaluations of traditional microcredit, the evidence does suggest that other forms of credit can benefit the poor. Commercial incentives align around credit delivery better than around some other products, (clients are willing to pay -- a lot), and we are just starting to see a new wave of "digital credit" products using calling and handset data to automate the delivery of credit over mobile. That said, we worry that provider incentives to not always align around key concepts like protecting client welfare or around reaching the poorest and we are already seeing some bad behavior. How do we guide the market to a good outcome for poor people? 
4. How to align incentives for reaching women and the poorest? Despite evidence that financial tools can help to empower women and the poorest, providers do not always have the incentives or business models to include these groups. Providers may not have incentives to address key sociological barriers and so passive rollouts of products like ATM cards may not meaningfully increase access for women and can even have perverse effects, (e.g. by allowing relatives easier access to their funds). However, there is emerging evidence that well-designed products that are cognizant of, and responsive to, social norms can empower women. What levers do we have to maximize the incentives to reach women and the poorest?

5. What are the best ways to leverage digital channels for G2P? The evidence shows that using digital methods for social protection transfers is a powerful tool that governments can use to align providers' private incentives with social incentives. How do we maximize the benefits of digital transfers while ensuring the least financially literate and less empowered groups are included?

6. How to connect finance to end goals? Finance is a means to an end. Various studies show interactions of finance with agriculture; girl school enrollment and maternal health; as well as uptake of sanitation services and solar lamps on PAYGO. How do we achieve tighter linkages between finance interventions and other sectors to magnify impact? 


\section{Appendix A}

Aker, Jenny C., Rachid Boumnijel, Amanda McClelland and Niall Tierney. 2014. "Payment

Mechanisms and Anti-Poverty Programs: Evidence from a Mobile Money Cash Transfer Experiment in Niger." Center for Global Development Working Paper 268.

Alan, Sule, Mehmet Cemalcilar, Dean Karlan, and Jonathan Zinman. 2015. "Unshrouding Effects on Demand for a Costly Add-on: Evidence from Bank Overdrafts in Turkey." NBER Working Paper No. 20956.

Almazan, M., Kendall, J., and Wright, G. 2013. "New Sales and Distribution Models in Mobile Financial Services", Working Paper, SSRN id 2241839.

Ashraf, Nava, Dean Karlan, and Wesley Yin. 2010. "Female Empowerment: Impact of a Commitment Savings Product in the Philippines." World Development 38(3): 3334.

Banerjee, Abhijit, Esther Duflo, Clement Imbert, Santosh Mathew, and Rohini Pande. 2016. “Can EGovernance Reduce Capture of Public Programs? Experimental Evidence from a Financial Reform in India's Employment Guarantee." Working Paper.

Banerjee, Abhijit, Esther Duflo, Nathanael Goldberg, Dean Karlan, Robert Osei, William Parienté, Jeremy Shapiro, Bram Thuysbaert, and Christopher Udry. 2015. "A Multifaceted Program Causes Lasting Progress for the Very Poor: Evidence from Six Countries." Science 348(6236), doi: 10.1126/science. 1260799.

Banerjee, Abhijit, Dean Karlan, and Jonathan Zinman. 2015. "Six Randomized Evaluations of Microcredit: Introduction and Further Steps." American Economic Journal: Applied Economics, 7(1): 121.

Beaman, Lori, Dean Karlan, and Bram Thuysbaert. 2014. "Saving for a (Not So) Rainy Day: A Randomized Evaluation of Savings Groups in Mali." NBER Working Paper No. 20600.

Benartzi, S. and Lehrer, J. 2015. "The Smarter Screen”, Penguin Press.

Benartzi, Shlomo and Thaler, Richard H. 2004. "Save More Tomorrow: Using Behavioral Economics to Increase Employee Saving." Journal of Political Economy, 112(1): S164S187.

Beshears, J., J. Choi, D. Laibson, and B. Madrian. 2008. "The Importance of Default Options for Retirement Saving Outcomes: Evidence from the United States." Working Paper.

Brune, Lasse, Xavier Gine, Jessica Goldberg, and Dean Yang. 2016. "Facilitating Savings for Agriculture: Field Experimental Evidence from Malawi." Economic Development and Cultural Change 64(2): 187-220.

Buehren, Niklas, Markus Goldstein, Tricia Gonwa, Leora Klapper, Robert Darko Osei, and Simone Schaner. Ongoing. "The Impact of Formal Savings on Salaried Workers' Spending and Borrowing in Eastern Ghana."

Cadena, Ximena, and Antoinette Schoar. 2011. "Remembering to Pay? Reminders vs. Financial Incentives for Loan Payments." NBER Working Paper No. 17020. 
Callen, Michael, Joshua E Blumenstock, Tarek Ghani, and Lucas Koepke. 2015. "Promises and Pitfalls of Mobile Money in Afghanistan: Evidence from a Randomized Control Trial”. Working Paper.

Casaburi, Lorenzo, and Jack Willis, 2015. "Interlinking Product and Insurance Markets: Experimental Evidence from Contract Farming in Kenya, Working Paper.

Cole, Shawn. 2009. "Fixing Market Failures or Fixing Elections? Agricultural Credit in India. "American Economic Journal: Applied Economics, 1(1): 21950.

Cole, Shawn A., Xavier Gine, Jeremy Tobacman, Petia Topalova, Robert M. Townsend, and James Vickery. 2013. "Barriers to Household Risk Management: Evidence from India." American Economic Journal: Applied Economics 5(1): 104-135.

Cole, Shawn, Xavier Gine, and James Vickery. 2013. "How Does Risk Management Influence Production Decisions? Evidence from a Field Experiment." Harvard Business School Working Paper.

Cole, Shawn A., Daniel Stein, and Jeremy Tobacman. 2014. "Dynamics of Demand for Index Insurance: Evidence from a Long-Run Field Experiment." American Economic Review: Papers and Proceedings 104(5): 284-290.

Cole, Shawn A., and Antoinette Schoar. Ongoing. "Rules of Thumb: Providing Timely Useful Financial Management Advice at Scale."

De Janvry, Alain, Craig McIntosh, and Elisabeth Sadoulet. 2010. "The supply- and demand-side impacts of credit market information." Journal of Development Economics 93, no. 2: 173188.

Drexler, Alejandro, Greg Fischer, and Antoinette S. Schoar. 2014. "Keeping it Simple: Financial Literacy and Rules of Thumb." American Economic Journal: Applied Economics 6(2): 131.

Dupas, Pascaline, and Jonathan Robinson. 2013a. "Savings Constraints and Microenterprise Development: Evidence from a Field Experiment in Kenya." American Economic Journal: Applied Economics 5(1): 163192.

Dupas, Pascaline, and Jonathan Robinson. 2013b. "Why Don't the Poor Save More? Evidence from Health Savings Experiments." American Economic Review, 103(4): 113871.

Dupas, Pascaline, Dean Karlan, Jonathan Robinson, and Diego Ubfal. 2016. “Expanding Access to Formal Savings Accounts. Experimental Evidence from Uganda, Malawi and Chile.” Working Paper.

Feigenberg, Benjamin, Erica Field, and Rohini Pande. 2013. "The economic returns to social interaction: Experimental evidence from microfinance." The Review of Economic Studies 80(4): 14591483.

Field, Erica, Seema Jayachandran, Rohini Pande, and Natalia Rigol. "Friends at Work: Can Peer Support Stimulate Female Entrepreneurship?” Forthcoming American Economic Journal: Applied Economics.

Field, Erica, Rohini Pande, John Papp, and Natalia Rigol. 2013. "Does the classic microfinance model discourage entrepreneurship among the poor? Experimental evidence from India." American Economic Review 103 (6), 2196-2226. 
Field, Erica, Rohini Pande, John Papp, and Y. Jeannette Park. 2012. "Repayment flexibility can reduce financial stress: A randomized control trial with microfinance clients in India." PLoS ONE 7 (9).

Field, Erica, Rohini Pande, Simone Schaner, and Natalia Rigol. Ongoing. "Financial Inclusion and Female Empowerment: An Evaluation of Banking Access on Women's Socioeconomic Status and Wellbeing."

Fink, Günther, B. Kelsey Jack, Felix Masiye. 2014. "Seasonal Credit Constraints and Agricultural Labor Supply: Evidence from Zambia.” NBER Working Paper No. 20218.

Giné, Xavier, Cristina Martinez Cuellar, and Rafael Keenan Mazer. 2014. "Financial (dis)information: Evidence from an audit study in Mexico." World Bank Policy Research Working Paper 6902.

Giné, Xavier, Jessica Goldberg, and Dean Yang. 2012. "Credit Market Consequences of Improved Personal Identification: Field Experimental Evidence from Malawi." American Economic Review 102(6): 29232954

Imbert, Clement and John Papp. 2015. “Labor Market Effects of Social Programs: Evidence from India's Employment Guarantee," American Economic Journal: Applied Economics, 7 (2), 233-263.

J-PAL and IPA Policy Bulletin. 2015. "Where Credit is Due." Cambridge, MA: Abdul Latif Jameel Poverty Action Lab and Innovations for Poverty Action.

Jack, William, Michael Kremer, Joost de Laat and Tavneet Suri. 2015. "Expanding Access to Micro Credit: The Role of Asset-Collateralized Loans." Working Paper.

Jack, William, Adam Ray, and Tavneet Suri. 2012. “Transaction Networks: Evidence from Mobile Money in Kenya." American Economic Review, Papers and Proceedings, 103 (3), pp. 356361.

Jack, William, and Tavneet Suri. 2014. "Risk Sharing and Transactions Costs: Evidence from Kenya's Mobile Money Revolution." American Economic Review, 104(1): 183223.

Jack, William, and Tavneet Suri. 2015. "The Longer Term Impacts of MPESA in Kenya”. Working Paper.

Karlan, Dean, and Leigh Linden. 2014. "Loose Knots: Strong versus Weak Commitments to Save for Education in Uganda." Working Paper.

Karlan, Dean, Melanie Morten, and Jonathan Zinman. 2015. "A Personal Touch: Text Messaging for Loan Repayment." NBER Working Paper 17952.

Karlan, Dean, Margaret McConnell, Sendhil Mullainathan, and Jonathan Zinman. 2014. "Getting to the Top of Mind: How Reminders Increase Saving." Management Science.

Karlan, Dean, Robert Osei, Isaac OseiAkoto, and Christopher Udry. 2014. "Agricultural Decisions after Relaxing Credit and Risk Constraints." The Quarterly Journal of Economics 129(2): 597652.

Karlan, Dean, Aishwarya L. Ratan, and Jonathan Zinman. 2014. "Savings by and for the Poor: A Research Review and Agenda." Review of Income and Wealth, 60: 36-78. 
Karlan, Dean, Beniamino Savonitto, Bram Thuysbaert and Christopher Udry. Ongoing. "The Impact of Village Savings and Loan Groups on Financial Inclusion and Household Welfare."

Karlan, Dean, and Jonathan Zinman. 2010. "Expanding Credit Access: Using Randomized Supply Decisions to Estimate the Impacts." Review of Financial Studies 23(1), pp. 433464

Karlan, Dean, and Jonathan Zinman. 2009. “Observing Unobservables: Identifying Information Asymmetries with a Consumer Credit Field Experiment.” Econometrica 77 (6): 19932008.

Miller, Margaret; Reichelstein, Julia; Salas, Christian; Zia, Bilal. 2014. “Can You Help Someone Become Financially Capable? A Meta-Analysis of the Literature.” World Bank.

Muralidharan, Karthik, Paul Niehaus, and Sandip Sukhtankar. "Building state capacity: Evidence from biometric smartcards in India." Forthcoming American Economic Review.

Prina, Silva. 2015. "Banking the Poor via Savings Accounts: Evidence from a Field Experiment." Journal of Development Economics, 115: 1631.

Schaner, Simone. 2015. "The Cost of Convenience? Transaction Costs, Bargaining Power, and Savings Account Use in Kenya." Working Paper.

Sitbon, Elisa. 2015. "Addressing competition bottlenecks in digital financial ecosystems." Journal of Payments, Strategy, and Systems 9(3).

Song, Changcheng. 2015. "Financial Illiteracy and Pension Contributions: A Field Experiment on Compound Interest in China." SSRN Working Paper.

Suri, Tavneet, William Jack and Thomas Stoker. 2012. "Documenting the Birth of a Financial Economy", Proceedings on the National Academy of Sciences, 109 (26), 1025710262.

Zimmermann, Laura. 2015. "Why Guarantee Employment? Evidence from a Large Indian Public Works Program," Working Paper, University of Georgia. 